\title{
Allelopathic Effect of Ecofriendly Botanical Extracts and Application of Vinasse as Alternative Source of Mineral Potassium Fertilizers on Yield and Oil Quality of Caraway Plant
}

\author{
Gehan F. Massoud ${ }^{1}$, A.S. Dapor ${ }^{1}$ and A.M. El-Shoura ${ }^{2}$ \\ ${ }^{I}$ Medicinal and Aromatic Plants Research Department, Horticulture Research Institute, ARC, Giza, \\ Egypt. \\ ${ }^{2}$ Cross pollinated vegetables Research Department, Horticulture Research Institute, ARC, Giza, \\ Egypt.
}

Received: 16 Sept. 2019 / Accepted 25 Nov. 2019 / Publication date: 10 Dec. 2019

\begin{abstract}
A field trial was performed during two consecutive winter seasons of 2017 and 2018 at a private farm located in Kafr El Wekala, Sherbin, El Dakahlia Governorate, Egypt to evaluate the allelopathic effect of garlic and licorice extracts at $0,1,2$ and $4 \%$ and application of vinasse as organic fertilizer at $\mathrm{V}_{1}(50 \%)$ and $\mathrm{V}_{2}(100 \%)$ from the recommended dose of potassium fertilizer on growth of caraway plants, seed measurements, essential oil productivity as well as $\mathrm{N}, \mathrm{P}, \mathrm{K}, \mathrm{Ca}, \mathrm{Mg}$ and $\mathrm{Fe}$ contents of caraway seeds. The obtained results showed that garlic and licorice extracts under both the chemical fertilizer NPK and levels of vinasse possess the positive allopathic effect on growth and the yield of caraway. Vinasse at two levels resulted in significant increments on all studied parameters compared to chemical fertilizer, Furthermore, the plants treated with the high rate of vinasse $(100 \%)$ in combinations with licorice extracts at $2 \%$ in both seasons recorded the maximum means values for growth characters, plant dry weight, seed weight per plant subsequently seed yield per fed. and essential oil production. Moreover, Vinasse (100\%) in combinations with garlic extracts at $4 \%$, significantly increased the chemical constituents of caraway seeds compared to the control and other treatments in both seasons. GCM analyses for oil showed that a total of 10 compounds, the main component was carvone which constitutes the maximum percentages in plants treated with vinasse $(100 \%)$ in combination with garlic foliar application at all levels. The obtained data revealed that the best growth, essential oil and chemical composition were obtained from treated plants with vinasse $(100 \%)$ from the recommended dose of $\mathrm{K}$ in combination with licorice extracts at $2 \%$ and garlic extract at $4 \%$ which had attained the uppermost values of yield and quality of caraway compared to either control or other treatments. Therefore, we recommend spraying caraway plants with ecofriendly, organic and costless extract of licorice at $2 \%$ and replacement of the mineral $\mathrm{K}$ fertilizers by vinasse $(100 \%)$ as an organic potassium source without adverse effects on caraway yield and oil quality.
\end{abstract}

Keywords: Carum carvi L., vinasse, allelopathic effect, garlic, licorice extracts, yield, quality of oil

\section{Introduction}

The production of safe and healthy foods using sustainable and environmentally friendly agricultural practices plays a vital role in determining their market value and nutritional benefits. For increasing productivity, a new strategy is using organic fertilizers and growth stimulating compounds that should be safe and inexpensive.

Caraway (Carum carvi L., Apiaceae) is one of the earliest cultivated herbs in Africa, Europe and Asia (Kamenik J., 1996). It was used in folk medicine, recently caraway has good antioxidant activity (Samojlik et al. 2010), possesses antifungal and antibacterial properties (Gupta et al. 2011). Also, it exerted antimicrobial, anticancer, antidiabetic, diuretic, gastrointestinal, bronchial relaxant effects and other pharmacological activities. It improves lactation in nursing mothers. In addition, it was used as a potato sprouting inhibitor (Șanli et al. 2010). The main criteria for determining the quality of caraway is its high content of essential oil, which is obtained by distillation of the dried fruit and gives its characteristic aroma (Sachan et al., 2010). Fruits are used as a spice in food due to its

Corresponding Author: Gehan, F. Massoud, Medicinal and Aromatic Plants Research Department, Horticulture Research Institute, ARC, Giza, Egypt.

E-mail: gehan.fawzy75@gmail.com 
pleasant flavour and for medicinal purposes (Bradley 2006 and Laribi et al., 2009). Caraway fruits typically contain up to $82 \mathrm{~cm}^{3} \mathrm{~kg}^{-1}$ of essential oil, the main components are carvone $(52 \%)$ and limonene (45\%) (OLLE and BENDER 2010). The vapor of caraway seeds is used to relieve rheumatism and lumbago.

Allelopathy used in agriculture since ancient times is a natural phenomenon in which plants interact through releasing allelochemicals hence affecting the growth of each other (Rice, 1984). The effect of allelochemicals may be positive or negative (Zhou et al., 2011) can stimulate or inhibit plant growth, and permit the development of plants with low phytotoxic residues (Zeng, 2008 and 2014). Several studies stated that garlic and licorice extracts influenced on growth parameters of the plant.

Garlic extract is rich in minerals, plant hormones, which induce cell enlargement and cell division, hence improve growth, fruit characters (Hanafy et al., 2012; Nour Eldeen, 2014 and Ziedan and Eisa, 2016). Garlic extracts possess allelopathic activity (Wei et al., 2008; Wang et al., 2009; Cheng et al., 2011; Cheng et al., 2016 and Ding et al., 2016). Garlic extract improves growth characters, flowering parameters, fruit yield and fruit quality (El-Shayeb, 2009; EL-Said and Ali, 2013; Mohamed and AkJadious, 2014 and Al-Obady, 2015).

Licorice roots are rich in minerals, vitamins, amino acid and phenolic compounds (Morsi et al., 2008 and Shabani et al., 2009). Foliar spraying with licorice extract has a favourable biological effect on the fresh and dry weight of plants, flowering, yield and fruit quality (Husain and El-Rekaby, 2006; Kamal and Ghanem, 2012 and Fathel et al., 2015). Many authors investigated the significant effects of Licorice extract as foliar application on the growth, flowering parameters, leaf area and foliage dry weight and chemical composition of several plants (Zuhair, 2010 on Fragaria $x$ ananassa Duch, Nasser et al., 2014 on Trigonella foenum-graecum and Abd El-Azim et al., 2017 on Foeniculum vulgare, Mill.) .

Potassium is an essential nutrient for a variety of process i.e. photosynthesis, fruit formation, winter hardiness and disease resistance. It plays an important role in protein formation, especially in grain filling. It is supplied by the fertilizer. Different sources of $\mathrm{K}$ for plants were produced from organic sources such as plant residues and compost. Alternative potassium source such as vinasse (an organic byproduct from ethanol production) was used to decrease the dependency on imported potassium fertilizers. Vinasse (an organic fertilizer) used as a potential source of organic matter and plant elements (N, K) with no poisonous residues (Parnaudeau et al., 2007 and Silva et al., 2015). It had a direct influence as a good alternative source for chemical fertilizers, and an indirect effect through the availability of the nutrients uptake and increased yield of wheat (Osman, 2010). Using of vinasse in combination with feldspar improved macronutrients in soil, contents of macro elements of grains of wheat and wheat yield (Seddik, 2011). Also, vinasse at the rate $75 \mathrm{t} / \mathrm{ha}$ increased the macro aggregates over control with a high amount of biodegradable $\mathrm{C}$ and $\mathrm{N}$ that has more significance to soil fertility (Jiang et al., 2012). Recently, Vadivel et al (2014) showed that the level of vinasse application and applicable time in agriculture improved the soil fertility and crop yields. The objectives of this work are to study allelopathic effects of garlic and licorice extracts and the application of vinasse as an alternative source of $\mathrm{K}$ fertilizer on the yield of caraway and oil quality.

\section{Materials and Methods}

To achieve the goal of this investigation, field trial was conducted during two successive winter seasons of 2017 and 2018 at a private farm situated in Kafr El Wekala, Sherbin, El Dakahlia Governorate which is located in northeast of the Nile Delta region (Latitudes $30^{\circ} 30^{\prime}$ and $31^{\circ} 30^{\prime} \mathrm{N}$; Longitudes $31^{\circ} 20^{\prime}$ and $32^{\circ} \mathrm{E}$ ), Egypt to evaluate allelopathic effect of garlic and licorice extracts at 0 , 1,2 and $4 \%$ under two levels of vinasse as organic fertilizer at $V_{1}(50 \%)$ and $V_{2}(100 \%)$ from the recommended dose of $\mathrm{K}$ on growth of caraway plants, seed measurements, essential oil productivity as well as $\mathrm{N}, \mathrm{P}, \mathrm{K}, \mathrm{Ca}, \mathrm{Mg}$ and Fe contents of caraway seeds. The soil samples supporting growth of caraway at $30 \mathrm{~cm}$ depth from soil surface before planting were analyzed at Mansoura Center of Soil Analysis and Improvement, using standard method designated by Page et al. (1982). Some mechanical and chemical properties of soil are presented in Table 1. 
Table 1: Some mechanical and chemical properties of the experimental soil.

\begin{tabular}{|c|c|c|c|c|c|c|c|}
\hline \multicolumn{2}{|c|}{ Parameters } & 2017 & 2018 & \multicolumn{2}{|c|}{ Parameters } & 2017 & 2018 \\
\hline \multirow{4}{*}{ ) } & Clay & 44.48 & 45.12 & \multirow{4}{*}{\multicolumn{2}{|c|}{$\begin{array}{l}\text { Organic matter (\%) } \\
\mathrm{CaCO}_{3}(\%) \\
\text { pH } \\
\text { E.C. }(\mathrm{mmohs} / \mathrm{cm})\end{array}$}} & 1.47 & 1.66 \\
\hline & Silt & 31.02 & 32.88 & & & 2.31 & 2.54 \\
\hline & \multirow{2}{*}{ Sand } & \multirow{2}{*}{23.60} & \multirow{2}{*}{21.04} & & & 8.1 & 7.87 \\
\hline & & & & & & 1.89 & 1.47 \\
\hline Soil textu & & Clay loamy & Clay loamy & \multirow{7}{*}{ 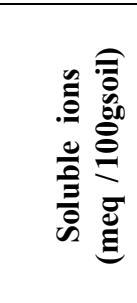 } & $\mathrm{Na}^{+}$ & 0.18 & 0.17 \\
\hline \multirow{6}{*}{ 党 } & $\mathbf{N}$ & 43.60 & 47.32 & & $\mathbf{C a}^{++}$ & 3.02 & 3.00 \\
\hline & $\mathbf{P}$ & 9.03 & 11.00 & & $\mathbf{M g}^{++}$ & 0.25 & 0.26 \\
\hline & $\mathbf{K}$ & 230.00 & 239.00 & & $\mathrm{HCO}_{3}^{-}$ & 0.50 & 0.70 \\
\hline & $\mathbf{F e}$ & 3.17 & 3.11 & & $\mathrm{Cl}^{-}$ & 0.40 & 0.36 \\
\hline & Zn & 1.27 & 1.28 & & $\mathrm{SO}_{3}{ }^{-}$ & 0.45 & 0.38 \\
\hline & Mn & 1.31 & 1.32 & & $\mathrm{CO}_{3}$ & - & - \\
\hline
\end{tabular}

Healthy seeds of caraway were attained from Medicinal and Aromatic Plants Dept. of Hort. Res. Inst., Agric. Res. Center. Seeds were sown on $17^{\text {th }}$ and $19^{\text {th }}$ October on two seasons, respectively in hills $(30 \mathrm{~cm})$ in between and on rows $(60 \mathrm{~cm})$ apart. The experimental unit area was $4.2 \mathrm{~m}^{2}$. Plants were thinned to one plant per hill. The Experimental design was a factorial experiment ( 3 X 7) in split plot design with three replicates. The main plots were assigned to a different application of chemical and vinasse fertilizers at $50 \%$ and $100 \%$ vinasse of recommended dose of $\mathrm{K}$ fertilizer, sub-plots were devoted to the foliar spray of natural extracts of Allium sativum and Glycyrrhiza glabra plants at $(0,1$, 2 and 4\%). The climatic conditions of the meteorological station within the experimental region were analyzed, maximum and minimum values were noted daily then recorded as mean / month (Table 2).

Control treatment was supplemented with mineral NPK fertilizer according to the recommendations of the Ministry of Agriculture; $200 \mathrm{~kg} /$ fed calcium superphosphate $\left(15.5 \% \mathrm{P}_{2} \mathrm{O}_{5}\right)$ during seed-bed preparation, nitrogen fertilizer $200 \mathrm{~kg} / \mathrm{fed}$ ammonium sulfate $(20.5 \% \mathrm{~N})$ which was added in two portions, half with all amounts of $\mathrm{K}$ fertilizer $50 \mathrm{~kg} /$ fed potassium sulfate $\left(48 \% \mathrm{~K}_{2} \mathrm{O}\right)$ after thinning of plants and the second after 45 days of the first. All treatments were fertilized by a recommended dose $\mathrm{N}$ and $\mathrm{P}$ fertilizers, while $\mathrm{K}$ fertilizer was added from vinasse at $50 \%$ and $100 \%$ of the potassium recommended dose of caraway.

Table 2: The climatic records of the meteorological station at El-Mansoura city during the two growing seasons (2017 and 2018).

\begin{tabular}{|c|c|c|c|c|c|c|c|c|c|c|c|c|c|c|}
\hline \multirow{3}{*}{ 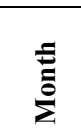 } & \multicolumn{7}{|c|}{$1^{\text {st }}$ season $(2017-2018)$} & \multicolumn{7}{|c|}{$2^{\text {nd }}$ season $(2018-2019)$} \\
\hline & \multicolumn{3}{|c|}{ Temp. ${ }^{\circ} \mathrm{C}$} & \multicolumn{3}{|c|}{ Rh \% } & \multirow{2}{*}{$\begin{array}{c}\mathbf{E v} \\
\mathbf{m m} / \mathbf{d a y}\end{array}$} & \multicolumn{3}{|c|}{ Temp. ${ }^{\circ} \mathrm{C}$} & \multicolumn{3}{|c|}{ Rh \% } & \multirow{2}{*}{$\begin{array}{c}\mathbf{E v} \\
\mathbf{m m} / \text { day }\end{array}$} \\
\hline & Max & Min. & Mean & Max & Min. & Mean & & Max. & Min. & Mean & Max & Min. & Mean & \\
\hline Oct. & 26.7 & 17.6 & 22.2 & 91.7 & 34.2 & 63.0 & 4.5 & 29.8 & 21.2 & 25.5 & 83.7 & 43.1 & 63.4 & 5.0 \\
\hline Nov. & 22.6 & 13.3 & 18.0 & 94.2 & 41.9 & 68.1 & 3.1 & 23.0 & 17.1 & 20.1 & 83.4 & 49.2 & 66.3 & 4.2 \\
\hline Dec. & 20.2 & 11.9 & 17.0 & 90.5 & 46.8 & 68.7 & 2.5 & 22.0 & 14.8 & 18.4 & 82.2 & 51.7 & 67.0 & 2.8 \\
\hline Jan. & 18.0 & 8.0 & 13.0 & 86.0 & 37.9 & 62.0 & 2.3 & 19.7 & 11.1 & 15.4 & 93.8 & 50.5 & 72.2 & 2.5 \\
\hline Feb. & 18.5 & 8.2 & 13.4 & 87.6 & 34.1 & 60.9 & 2.1 & 22.7 & 11.8 & 17.3 & 93.1 & 45.3 & 69.2 & 2.6 \\
\hline Mar. & 22.7 & 8.8 & 15.8 & 87.9 & 29.7 & 58.8 & 2.7 & 23.7 & 12.9 & 18.3 & 93.1 & 42.4 & 67.8 & 3.3 \\
\hline Apr. & 26.8 & 14.6 & 20.7 & 93.2 & 34.8 & 64.0 & 4.6 & 26.6 & 13.4 & 20.0 & 89.6 & 38.7 & 64.2 & 4.3 \\
\hline May. & 27.5 & 15.9 & 21.7 & 93.3 & 31.0 & 62.2 & 4.8 & 29.5 & 17.4 & 23.5 & 83.6 & 38.7 & 61.2 & 5.4 \\
\hline Jun. & 32.1 & 20.1 & 26.1 & 90.7 & 28.4 & 59.6 & 5.5 & 33.7 & 22.5 & 28.1 & 83.0 & 37.6 & 60.3 & 6.2 \\
\hline
\end{tabular}

Temp.: temperature Rh: Relative humidity Ev: Evaporation

Vinasse treatments were sprayed two weeks after planting on soil surface three times along the period of plant growth after $\left(2,4\right.$ and 6 weeks) from planting as $375 \mathrm{~L} \mathrm{fed}^{-1}(50 \%)$ and $750 \mathrm{~L} \mathrm{fed}^{-1}(100 \%)$ from the recommended dose. Entirely agricultural practices were performed according to the recommendations of Egyptian Ministry of Agriculture. Caraway required from 5 to 7 irrigations till the umbels were filled with mature seeds. Vinasse was obtained from the integrated industries and 
sugar Company, EL-Hawamdia, Egypt. Some chemical characteristics of vinasse are shown in Table 3.

Table 3: Some chemical characteristics of vinasse

\begin{tabular}{cccccccccccc}
\hline pH & $\begin{array}{c}\text { E.C. } \\
\mathbf{d S m}^{-1}\end{array}$ & $\begin{array}{c}\text { Density } \\
\mathbf{~ g ~ m l}^{-1}\end{array}$ & $\begin{array}{c}\text { Organic } \\
\text { matter (\%) }\end{array}$ & $\begin{array}{c}\text { Total } \\
\text { phenols (\%) }\end{array}$ & N & P & K & Ca & Mg & Fe & Mn \\
\hline 4.18 & 20.3 & 1.25 & 18.4 & 0.15 & 1.40 & 0.39 & 6.40 & 0.70 & 0.45 & 0.03 & 0.002 \\
\hline
\end{tabular}

Foliar treatments with licorice root and garlic extracts were applied three times at 30, 45 and 60 days from planting. The aqueous extract of licorice roots was prepared by blending $(10,20 \mathrm{or} 40 \mathrm{~g})$ in one litre of distilled water $50^{\circ} \mathrm{C}$ for 24 hours. The solution filtered by wringing using a mutton cloth. The obtained extract re-filtered through Whatman No. 2 filter paper and completed by distilled water to one litre. Egyptian licorice roots, according to Morsi et al (2008) contains K (480.2), Ca (984.0), $\mathrm{Mg}$ (473.5), Fe (25.27) and $\mathrm{Mn}$ (1.25) as well as total phenols (405.0) and total flavonoids (114.9) $\mathrm{mg} / 100 \mathrm{~g}$ dry weight. The 1,2 and $4 \%$ garlic aqueous extract was prepared by blending 10, 20 and 40 $\mathrm{g}$ of fresh mature cloves in one litre of distilled water, frozen and thawed two times, and then filtered and diluted by distilled water to one litre (El-Desouky et al., 1998). Garlic bulbs as mentioned by Duke (1992) contain minerals as K (3,730-13,669), Mg (240-1,210), Fe (15-129), Ca (180- 4,947), B (3-6) and Cr (2.5-15)ppm; amino acids such as Arginine (6,340-15,216), Glutamic-acid (8,05019,320), Aspartic acid (4,890-11,736) Methionine (760-1,824), Phenylalanine (1830-4,392) and Proline (1,000-2,400)ppm; vitamin such as ascorbic acid (100-788) ppm; terpenes and their derivatives as well as growth regulators such as gibberellin $\mathrm{A}_{3}$.

The following parameters were recorded as average of plant height $(\mathrm{cm})$, number of branches per plant, plant dry weight (g), number of umbels per plant and number of umbelet per umbels. Some seed measurements; Dry weight of seeds $\left(\mathrm{g} \mathrm{plant}^{-1}\right)$, Yield of dry seeds $\left(\mathrm{kg} \mathrm{fed}^{-1}\right)$, thousand seed weight (g), harvest index (the ratio of seed yield per plant to the total above ground according to Ullah et al., 2006). The harvest took place in $20^{\text {th }}$ and $25^{\text {th }}$ June for both seasons manually by cutting plants then drying them up. Ripe caraway was threshed in a small plot harvester. For the chemical analyses, representative samples of seeds each were digested in a mixture of concentrated sulfuric acid and perchloric acids. Total nitrogen was determined in dried samples (A.O.A.C., 1990). Phosphorus was determined colorimetrically according to Murphy and Riley (1962). K, Mg, Ca and $\mathrm{Fe}$ were determined according to Chapman and pratt, 1961. Essential oil determinations; the dried seeds of caraway were hydrodistilled in a Clevenger's type apparatus. Yellow coloured oil, with characteristic odour and the sharp taste was obtained. It was dried over anhydrous sodium sulphate to eliminate traces of moisture and stored in a refrigerator in the dark at $4^{\circ} \mathrm{C}$ until use. The essential oil percentage was calculated owing to the method described by British Pharmacopoeia (2000). Oil yield (ml plant ${ }^{-1}$ ) and total yield $\left(\mathrm{kg} \mathrm{fed}^{-1}\right)$ were calculated. The analysis of volatile oil of interaction treatments was performed separately with a Hewlett- Packard model 5890. A fused silica capillary column carbowax $20 \mathrm{M}$ measuring $20 \mathrm{~m} \times 0.32 \mathrm{~mm}$ internal diameter, the film thickness of $0.17 \mu \mathrm{m}$. The temperature program adopted was maintained at $75^{\circ} \mathrm{C}$ for $5 \mathrm{~min}$. with an increase of $4^{\circ} \mathrm{C} / \mathrm{min}$ until $220^{\circ} \mathrm{C}(10 \mathrm{~min}$.). The carrier gas was Helium and the working flow rate was $1.0 \mathrm{ml} / \mathrm{min}$, the detector was $9144 \mathrm{HP}$. The temperature of the detector and injector were adopted at $280^{\circ} \mathrm{C}$ and $240^{\circ} \mathrm{C}$, respectively. The identification of the separated compounds was achieved by matching their retention times with those of authentic samples injected under the same conditions.

Statistical analysis was carried out according to Gomez and Gomez (1984) using CoStat. The obtained data were subjected to analysis of variance (ANOVA) and the means were compared using the least significant differences (L.S.D) at 5\%.

\section{Results and Discussion}

\section{1- Vegetative growth characters}

Regarding to impact of NPK as chemical fertilization, vinasse as organic fertilization and allelopathic effect of garlic and licorice extracts on dry weight and some vegetative growth parameters of caraway, obtained results in Table (4) indicated that all applied treatments stimulated 
Table 4: Effect of vinasse and natural extracts of garlic and licorice on some vegetative growth characters and plant dry weight of Carum carvi L. during the two seasons of 2017/2018 and 2018/2019.

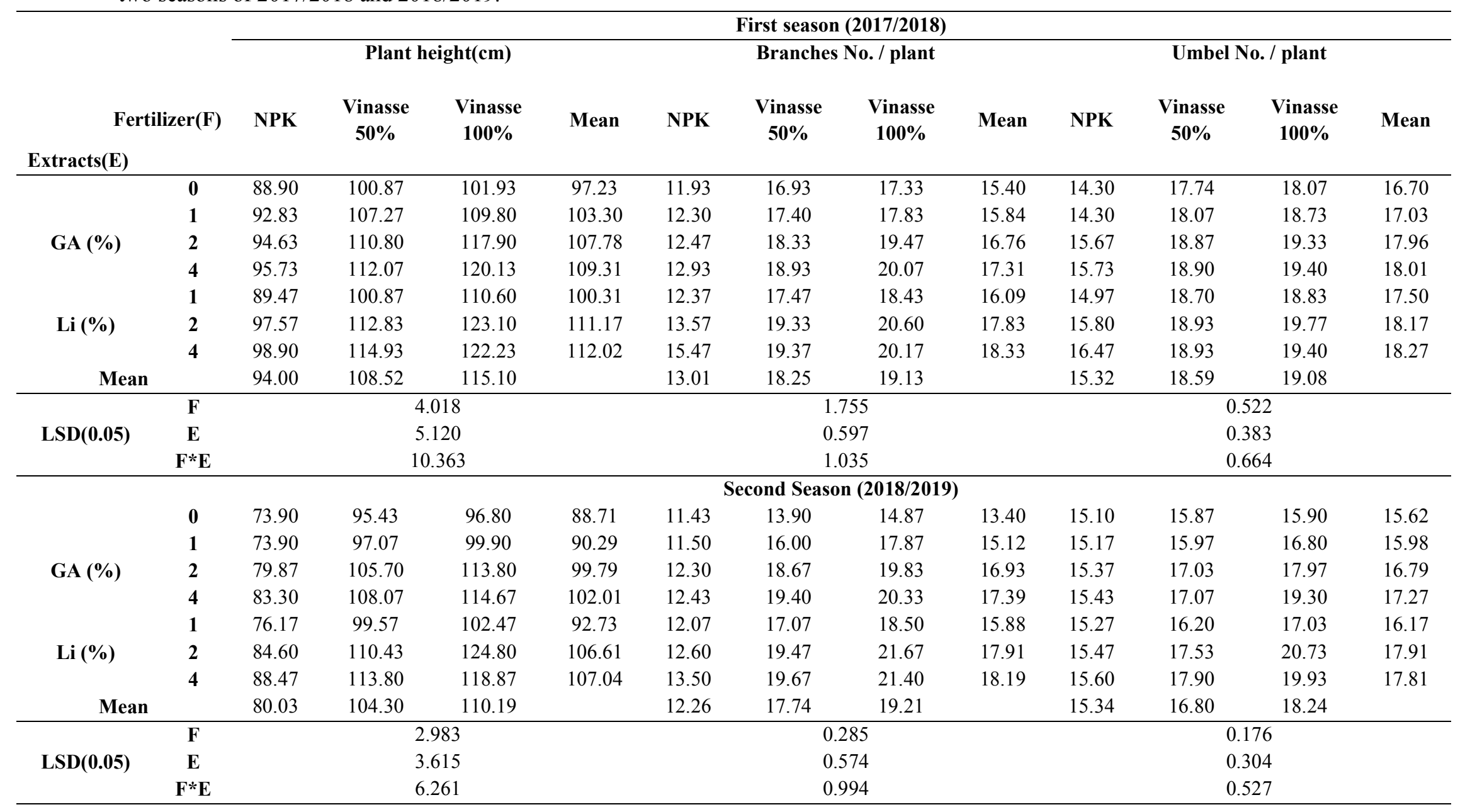




\section{Table 4: Continued}

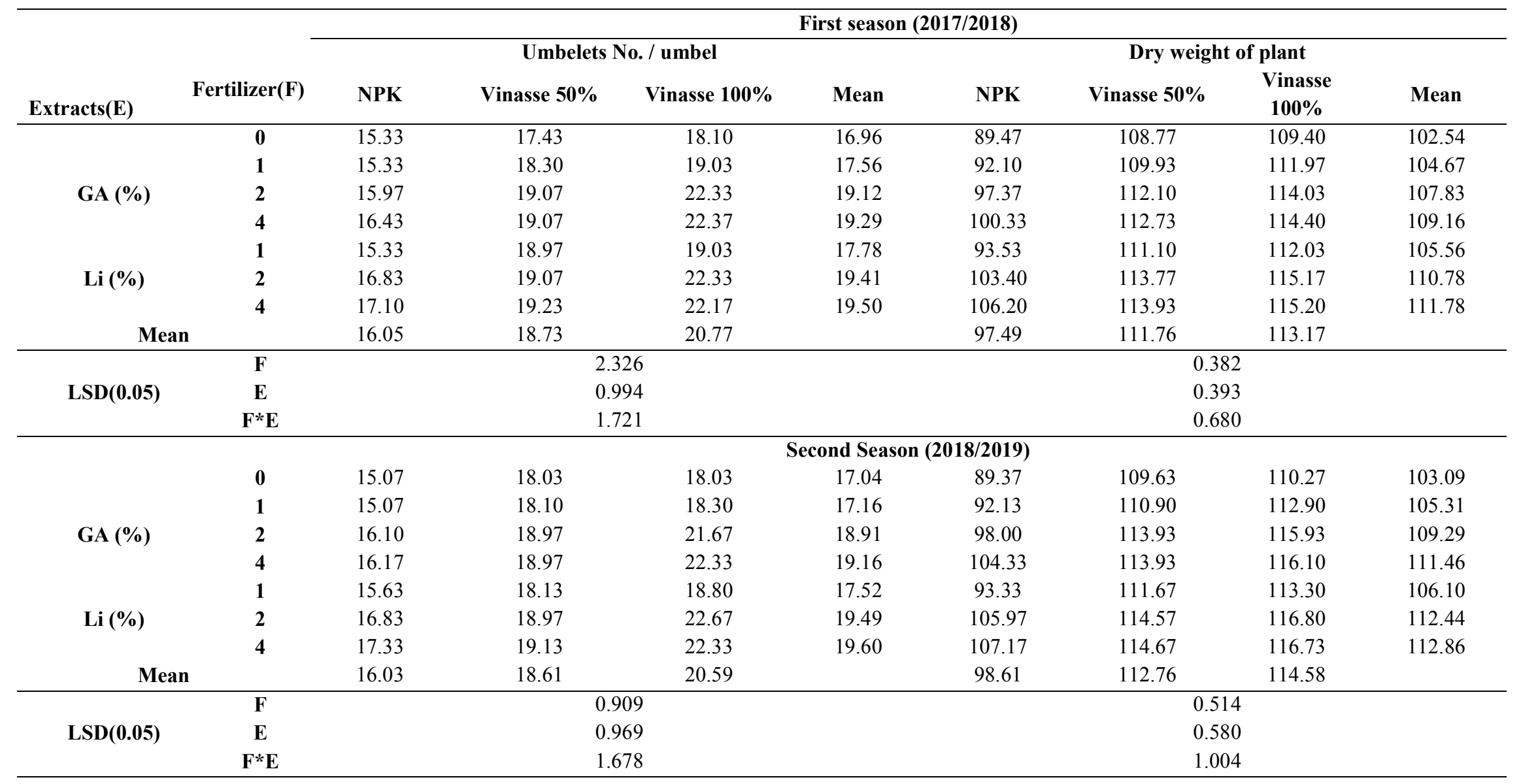


considerably plant height, number of branches per plant, number of umbels per plant, number of umbelets per umbel and dry weight of caraway as compared to control treatment in this respect in the two growing seasons. Foliar spraying of licorice extract at all levels led to significant increase in height of caraway plants, number of branches as well as number of umbels and umbelets number. These findings are in harmony with those found by (Nasser et al., 2014 and Abd El -Azim et al., 2017), also foliar application of garlic extract at high rates significantly enhanced growth characters, these results are similar to those obtained by (El-Shayeb, 2009; EL-Said and Ali, 2013 and Al-Obady, 2015). Vinasse treatments at both two levels showed increments in the studied growth parameters, in this concern, Vadivel et al. (2014) stated that addition of various levels of vinasse in agriculture stimulated crop yields, increased a significant amount of nutrients and amended the soil quality of degraded land. These may be attributable to the positive effect of vinasse on encouraging microflora populations, and increase of microbial biomass thus improving the soil fertility status and enhanced crop production (Shang-Dong et al., 2013). It is obvious that the treatment of the high level of vinasse $\mathrm{V}_{2}(100 \%)$ in combinations with foliar spraying of garlic $(4 \%)$ or licorice $(2 \%)$ extracts significantly improved caraway growth traits and exceeded all other treatments in both branch and umbel numbers as well as umbletes number and dry weight of caraway plant. The other treatments recorded an intermediate values in both seasons.

\section{2- Effect on seed measurements:}

Table (5) clear that the highest seed yield per plant and per fed. were verified when the treatments of vinasse $\left(\mathrm{V}_{2}\right)$ in combinations with foliar spraying of licorice $(2 \%)$ were used followed by vinasse $\left(\mathrm{V}_{2}\right)$ in combinations with foliar spraying of garlic $(4 \%)$ applied without significance among them in both seasons. Also, the heaviest 1000 seeds and the highest harvest index percentage followed the same trend as in the highest seed yield per plant. Such effect was confirmed in the two successive seasons, this may be due to the positive allelopathic effect of garlic and licorice extract which rich in vitamins, amino acids and minerals so improves flowering, fruit yield and fruit quality. These results are in covenant with those of EL-Said and Ali, 2013; Fathel et al., 2015; Cheng et al., 2016 and Ding et al., 2016. Generally, data revealed that plants receiving a high concentration of vinasse $\left(\mathrm{V}_{2}\right)$ recognized increments concerning the optimum yield of caraway as related to low concentration $\left(\mathrm{V}_{1}\right)$, these due to better nutritional elements required for plant growth. Vinasse is a good source of available $\mathrm{K}$ when smeared to the soil and its application may reduce the quantity of fertilizers needed for crop yield (Arafat and Yassen, 2002). Also, vinasse may be used as soil conditioners, which improve the availability of the nutrients thus increase yield (Omar et al., 2000).

\section{3- Essential oil productivity}

Data presented in Table (6) showed that, as vinasse fertilization level increased from $V_{1}$ up to $100 \%\left(\mathrm{~V}_{2}\right)$ of the recommended dose, oil yield per plant and per fed. was increased. The highest oil yield was recorded in plants received $\mathrm{V}_{2}(100 \%$ of the recommended NPK dose) during both seasons. As for the effect of spraying natural extracts of licorice and garlic on caraway oil production, obtained results revealed that spraying plants with licorice and garlic extract at all tested concentrations enhanced essential oil production per plant and per fed. comparing to unsprayed control plants in the two seasons. The most effective treatment in this concern was spraying licorice extract at $2 \%$ (produced 2.9- $2.9 \%, 1.51-1.62 \mathrm{ml}$ and 31.80 - $33.92 \mathrm{~L}$ oil percentage, essential oil per plant and per fed. for both seasons, respectively) followed by spraying treatment of garlic extract at $4 \%$ (resulted 2.87- $2.9 \%, 1.44-1.58 \mathrm{ml}$ and 30.24- 33.06 L for both seasons, respectively). When NPK chemical fertilization or vinasse at two levels interacted with extracts of licorice or garlic spraying, significant effects on oil production per plant and per fed. were detected as compared to unsprayed plants. The highest essential production/ plant was found in plants subjected to the treatment of vinasse at $V_{2}$ dose in combination with spraying with licorice extract at $2 \%$. These interaction effects on oil production/ plant were reflected on oil production/ fed and this confirmed in the two experimental seasons. 


\section{4- Constituents of essential oil}

Ten compounds were detected and identified as shown in Table (7). All studied treatments showed that carvone is the main constituents essential oil (56.22- 66.34\%), followed by limonene which varied from (12.91 to $17.01 \%)$ then $\alpha$-guaiene $(2.13-5.49 \%$ ) as well as linalool which ranged from (1.30 to $2.53 \%)$. The other identified compounds were acoradien, estragole, $\alpha-$ gurjunene, $\beta$ caryophyllene, 2, 6- dihydroxyacetophenone, and $\alpha$-pinene. These results are in harmony with those found by Olle and Bender, (2010).

\section{5- Chemical Constituents}

Caraway seeds are also a rich source of macro as well as micronutrients (Kluszczyñska 2002). A significant effect of vinasse fertilization alone or in combination with foliar spraying of licorice or garlic extract on the chemical composition of caraway seed was found (Table 8). All the different rates of vinasse fertilizer clearly increased the mean content of total $\mathrm{N}, \mathrm{P}, \mathrm{K} \mathrm{Ca}, \mathrm{Mg}$ and Fe in seeds. The highest average of total $\mathrm{N}$ and $\mathrm{P}$ contents were 3.61 and $0.58 \%$ in the first season while, 3.63 and $0.60 \%$ in the second season, respectively resulting from the fertilization treatment with the highest rates of vinasse $\left(\mathrm{V}_{2}\right)$ interacted with highest rates of garlic extract $(4 \%)$.

Regarding macro and microelements in caraway seeds, results in Table 8 showed steady increases during the two seasons as the level of vinasse fertilizer increased from $50 \%$ up to $100 \%$ of the recommended dose compared to NPK fertilizer. For the allelopathic effect of foliar spray of natural extracts of garlic and licorice on $\mathrm{K}, \mathrm{Ca}, \mathrm{Mg}$ and $\mathrm{Fe} \%$ in caraway seeds, the obtained data showed that all tested extracts treatments increased the studied elements in seeds in the two seasons compared to unsprayed control treatment. Besides, the spray treatment of licorice extract at $4 \%$, followed by the spray treatment of garlic extract at 4\% under the utilization of the highest rate of vinasse $(100 \%$ of the recommended dose) recorded the highest $\mathrm{K}$ percentages seeds for both seasons. On the other hand, the spray treatment of garlic extract at $4 \%$ under the utilization of the highest rate of vinasse (100\% of the recommended dose) recorded the maximum percentages of $\mathrm{Ca}, \mathrm{Mg}$ and $\mathrm{Fe}$ in seeds for both seasons. Respecting effect interaction treatments between NPK fertilization, vinasse fertilization and foliar spray of extracts of garlic or licorice on the studied elements in seeds, data in Table 8 showed that spraying tested extracts at certain rates under both tested fertilizer increased percentages of studied elements in caraway seeds as compared to the same fertilizer without spraying. Also, vinasse fertilization under any tested extract application increased the seed contents of the nutrients comparing to the same spray application with NPK fertilization. In general, the superior values of nutrients were found in plant seed of subjected plants to interaction treatments between full vinasse fertilizer dose and a foliar spraying of garlic extract at $4 \%$ or licorice extract at 2 or $4 \%$. These results are in covenant with those of Shang-Dong et al., 2013; Al-Obady, 2015 and Seddik et al., 2016.

\section{Conclusion}

From the above mentioned results, it could be concluded that all the tested fertilization treatments and all tested natural extracts each alone or interacted with other significantly increased vegetative parameters and seed measurements of caraway plants. The combination of vinasse $(100 \%)$ with foliar spraying of licorice extract at the rate of $2 \%$ was the most effective treatment in this respect. The results indicated that both garlic and licorice extracts under chemical fertilizer NPK and levels of vinasse as organic fertilizer possess a positive allopathic effect on growth, the yield of caraway so biomass was stimulated with these treatments. Also, data emphasized that caraway plants produce the highest oil yield with the highest quality and the superior contents of nutrients in response to the same treatments, where the application of vinasse to the soil has increased the availability of macronutrients in the soil especially $\mathrm{K}$ and organic matter which improved crop yield. It could be concluded that the importance of the use of vinasse alone or in combination with natural extracts of garlic and licorice as alternative sources for $\mathrm{K}$ - fertilizers and beneficial cheap sources of $\mathrm{K}$ fertilization for agriculture. 
Table 5: Effect of vinasse and natural extracts of garlic and licorice on seed measurements of Carum carvi L. during 2017/2018 and $2018 / 2019$.

\begin{tabular}{|c|c|c|c|c|c|c|c|c|c|c|c|c|c|c|c|c|c|}
\hline \multirow[b]{3}{*}{$\begin{array}{r}F \\
\text { Extract }\end{array}$} & \multirow[b]{3}{*}{$\begin{array}{l}\text { Fertilizer } \\
\text { t }\end{array}$} & \multicolumn{16}{|c|}{$\begin{array}{l}\text { First season }(2017 / 2018) \\
\end{array}$} \\
\hline & & \multicolumn{4}{|c|}{ Seed yield /plant (g) } & \multicolumn{4}{|c|}{ Seed yield /fed. (kg) } & \multicolumn{4}{|c|}{ Weight of 1000 seeds (g) } & \multicolumn{4}{|c|}{ Harvest Index (\%) } \\
\hline & & $\frac{v}{z}$ & 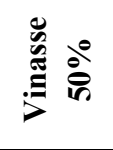 & 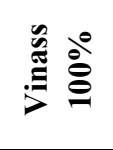 & $\sum_{\Sigma}^{\tilde{E}}$ & $\frac{v}{z}$ & 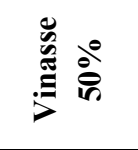 & 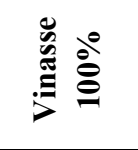 & $\sum_{\Sigma}^{\bar{E}}$ & $\frac{y}{z}$ & 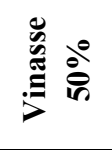 & 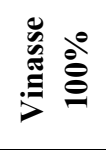 & 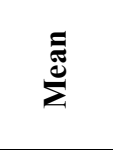 & $\frac{v}{\bar{z}}$ & 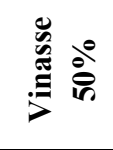 & 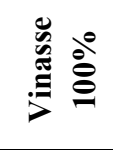 & $\sum_{\bar{E}}^{\bar{E}}$ \\
\hline \multirow[t]{2}{*}{$\mathbf{0}$} & & 33.13 & 45.50 & 47.00 & 41.88 & 695.73 & 955.50 & 987.00 & 879.41 & 13.93 & 16.20 & 16.27 & 15.47 & 37.04 & 41.83 & 42.96 & 40.61 \\
\hline & 1 & 40.33 & 47.80 & 49.20 & 45.78 & 847.00 & 1003.80 & 1033.20 & 961.33 & 15.03 & 16.43 & 17.10 & 16.19 & 43.79 & 43.48 & 43.94 & 43.74 \\
\hline \multirow{2}{*}{$\varangle e^{\ominus}$} & 2 & 40.13 & 49.97 & 50.17 & 46.76 & 842.80 & 1049.30 & 1053.50 & 981.87 & 15.10 & 17.57 & 19.33 & 17.33 & 41.22 & 44.57 & 43.99 & 43.26 \\
\hline & 1 & 40.33 & 48.47 & 49.90 & 46.23 & 847.00 & 1017.80 & 1047.90 & 970.90 & 15.03 & 16.73 & 17.37 & 16.38 & 43.12 & 43.62 & 44.54 & 43.76 \\
\hline \multirow{3}{*}{$=\underset{\text { Mean }}{e}$} & 2 & 41.83 & 50.07 & 52.20 & 48.03 & 878.50 & 1051.40 & 1096.20 & 1008.70 & 15.27 & 18.17 & 20.37 & 17.93 & 40.46 & 44.01 & 45.33 & 43.27 \\
\hline & 4 & 43.40 & 50.13 & 50.27 & 47.93 & 911.40 & 1052.80 & 1055.60 & 1006.60 & 15.83 & 18.90 & 20.33 & 18.36 & 40.87 & 44.00 & 43.63 & 42.83 \\
\hline & & 39.98 & 48.85 & 49.85 & & 839.49 & 1025.90 & 1046.90 & & 15.04 & 17.36 & 18.61 & & 41.01 & 43.70 & 44.04 & \\
\hline \multirow{3}{*}{ ન્ } & $\mathbf{F}$ & 0.621 & & & & 13.032 & & & & 0.492 & & & & 0.754 & & & \\
\hline & $\mathbf{E}$ & 0.666 & & & & 13.976 & & & & 0.248 & & & & 0.782 & & & \\
\hline & $F^{*} E$ & 1.153 & & & & 24.206 & & & & 0.429 & & & & 1.354 & & & \\
\hline \multicolumn{18}{|c|}{ Second Season $(2018 / 2019)$} \\
\hline $\mathbf{0}$ & 1 & 39.03 & 44.07 & 48.83 & 43.98 & 819.70 & 925.40 & 1025.50 & 923.53 & 15.07 & 18.17 & 19.93 & 17.72 & 42.37 & 39.74 & 43.26 & 41.79 \\
\hline \multirow{3}{*}{$\mathbb{b}$} & 2 & 40.37 & 50.67 & 54.17 & 48.40 & 847.70 & 1064.00 & 1137.50 & 1016.40 & 15.80 & 20.13 & 21.03 & 18.99 & 41.20 & 44.47 & 46.72 & 44.13 \\
\hline & 4 & 41.17 & 51.27 & 54.27 & 48.90 & 864.50 & 1076.60 & 1139.60 & 1026.90 & 16.07 & 20.43 & 21.07 & 19.19 & 39.46 & 44.99 & 46.74 & 43.73 \\
\hline & 1 & 39.87 & 44.97 & 49.33 & 44.72 & 837.20 & 944.30 & 1036.00 & 939.17 & 15.27 & 18.97 & 20.03 & 18.09 & 42.71 & 40.27 & 43.55 & 42.18 \\
\hline \multirow{3}{*}{$\exists e_{\text {Mean }}^{e}$} & 2 & 41.90 & 52.40 & 55.70 & 50.00 & 879.90 & 1100.40 & 1169.70 & 1050.00 & 16.33 & 20.70 & 21.13 & 19.39 & 39.54 & 45.74 & 47.69 & 44.32 \\
\hline & 4 & 42.70 & 53.93 & 54.33 & 50.32 & 896.70 & 1132.60 & 1141.00 & 1056.77 & 16.83 & 20.90 & 21.07 & 19.60 & 39.84 & 47.04 & 46.54 & 44.47 \\
\hline & & 39.94 & 48.66 & 51.52 & & 838.70 & 1021.90 & 1082.00 & & 15.73 & 19.58 & 20.33 & & 40.54 & 43.11 & 44.92 & \\
\hline \multirow{3}{*}{ 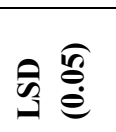 } & $\mathbf{F}$ & 0.425 & & & & 8.931 & & & & 0.240 & & & & 0.490 & & & \\
\hline & $\mathbf{E}$ & 0.731 & & & & 15.346 & & & & 0.133 & & & & 0.728 & & & \\
\hline & $F^{*} E$ & 1.266 & & & & 26.581 & & & & 0.231 & & & & 1.261 & & & \\
\hline
\end{tabular}


Table 6: Effect of vinasse and natural extracts of garlic and licorice on essential oil productivity of Carum carvi L. during 2017 and 2018.

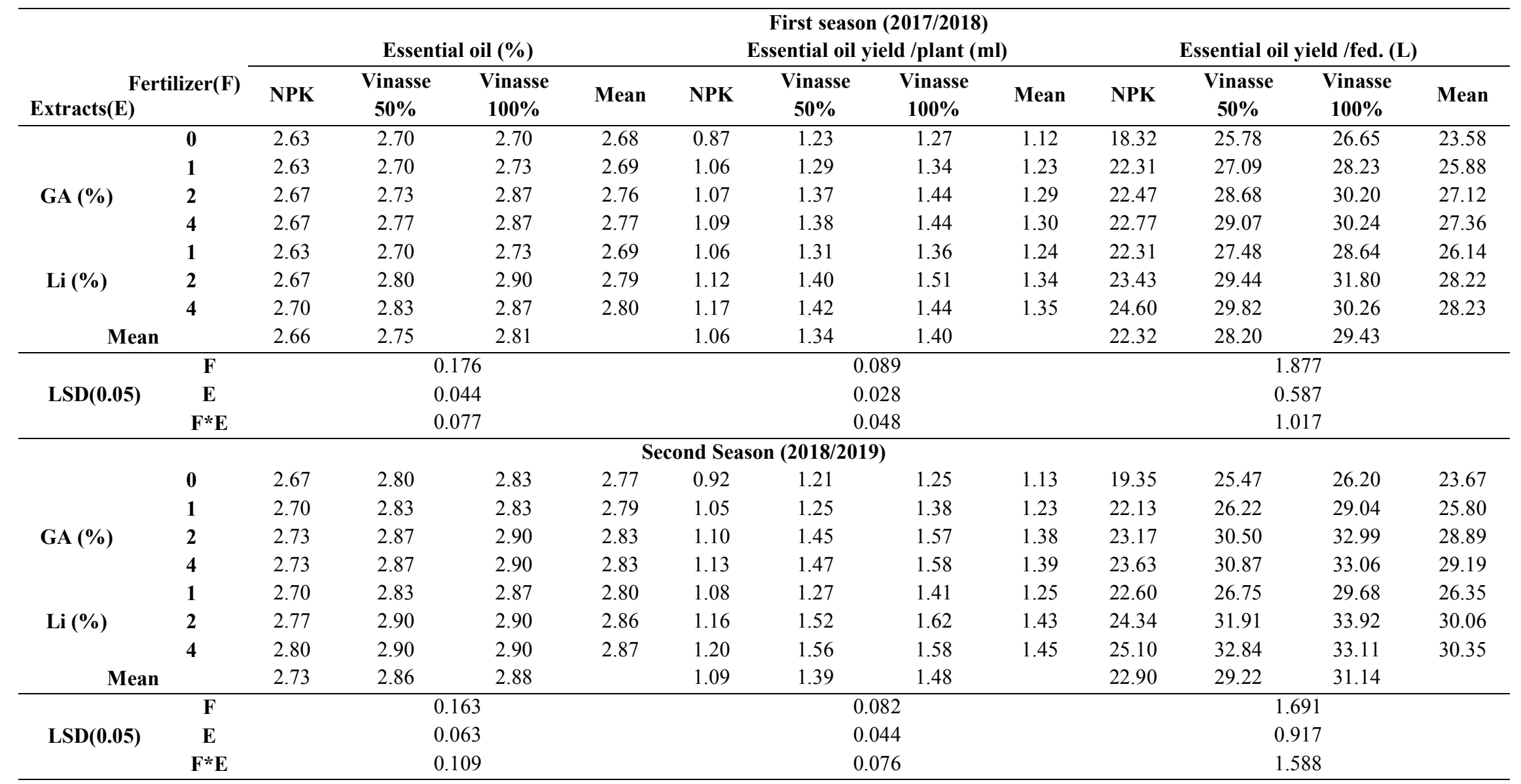


Table 7: Effect of NPK, vinasse and foliar application of garlic and licorice extracts on essential oil constituents (\%) of Carum carvi L. in the second season of $2018 / 2019$.

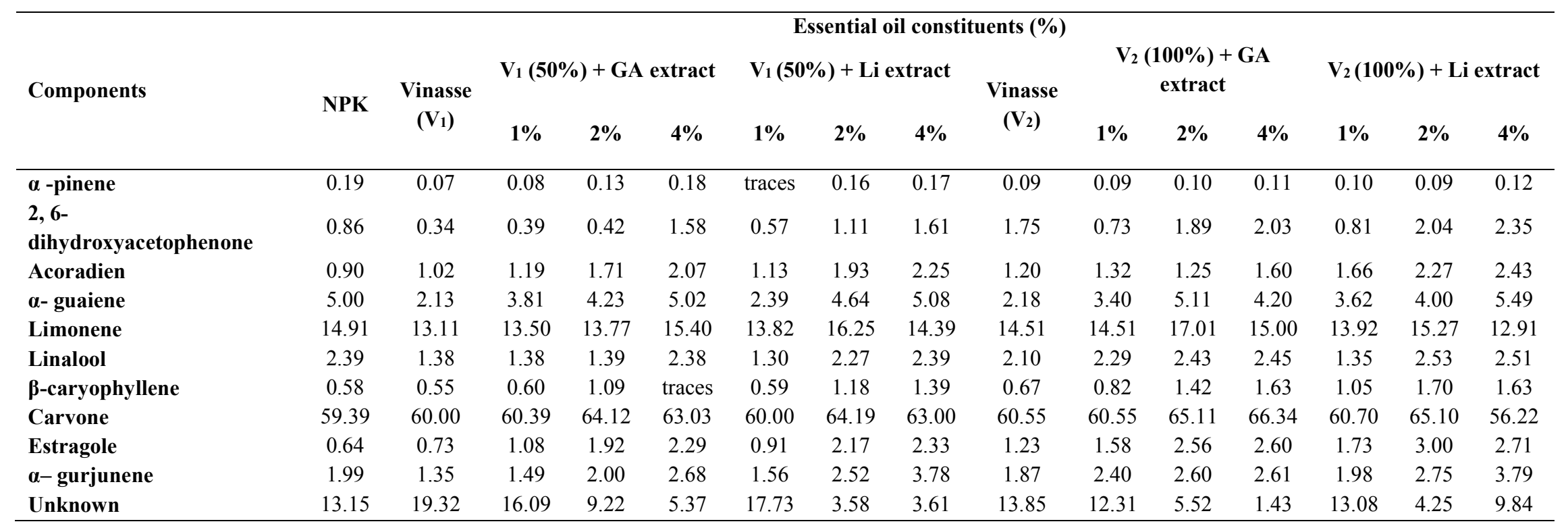


Table 8: Effect of vinasse and natural extracts of garlic and licorice on nitrogen, phosphorus, potassium, calcium, magnesium and iron contents (\%) of Carum carvi L. during the two seasons of 2017/2018 and 2018/2019.

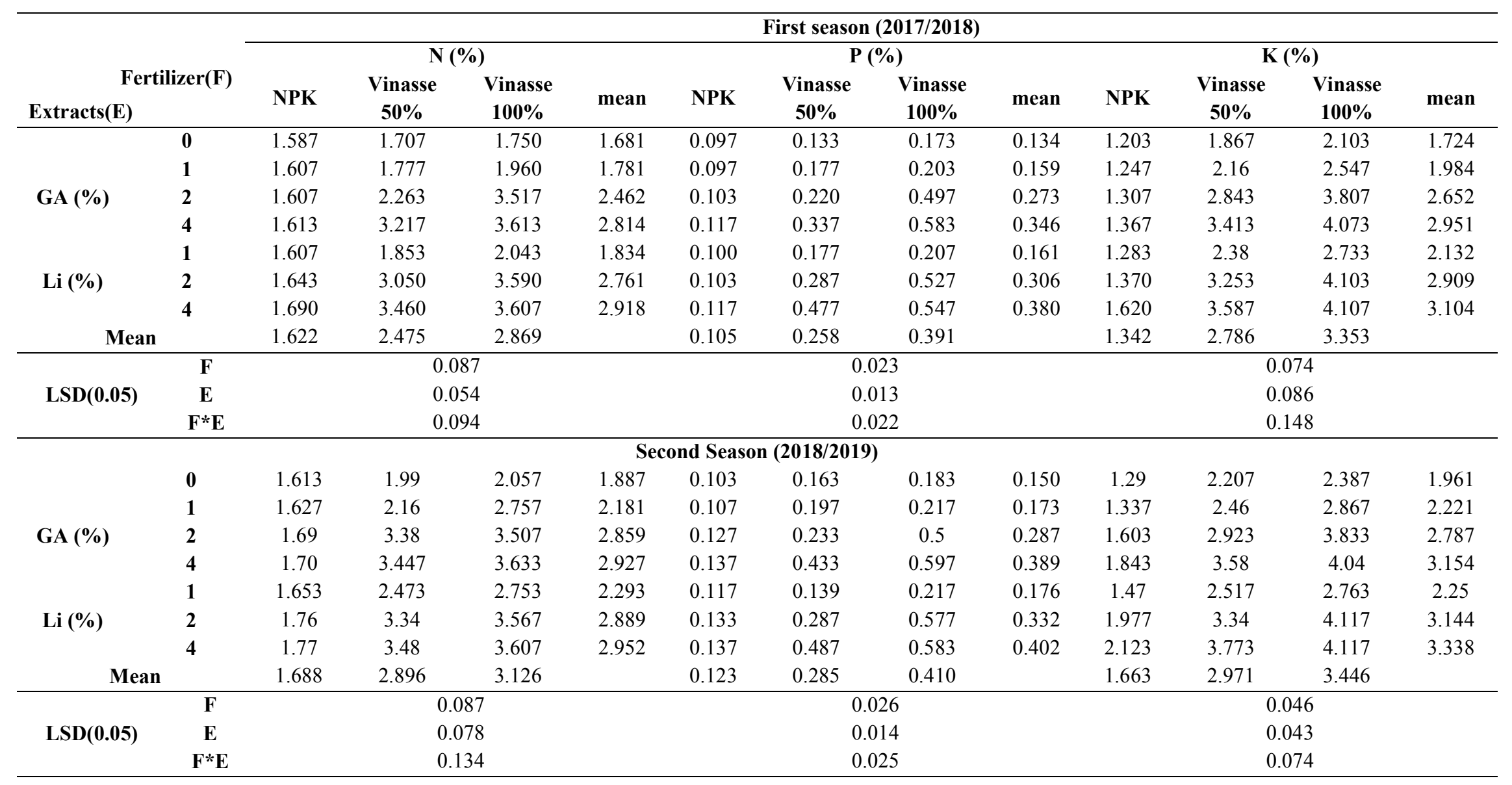




\section{Table 8: Continued}

\begin{tabular}{|c|c|c|c|c|c|c|c|c|c|c|c|c|c|}
\hline \multirow[b]{3}{*}{ Extracts(E) } & \multirow{3}{*}{ ertilizer(F) } & \multicolumn{12}{|c|}{ First season $(2017 / 2018)$} \\
\hline & & \multicolumn{4}{|c|}{ Ca $(\%)$} & \multicolumn{4}{|c|}{$\operatorname{Mg}(\%)$} & \multicolumn{4}{|c|}{ Fe $(\%)$} \\
\hline & & NPK & $\begin{array}{c}\text { Vinasse } \\
50 \%\end{array}$ & $\begin{array}{c}\text { Vinasse } \\
100 \%\end{array}$ & Mean & NPK & $\begin{array}{c}\text { Vinasse } \\
50 \%\end{array}$ & $\begin{array}{c}\text { Vinasse } \\
100 \%\end{array}$ & mean & NPK & $\begin{array}{c}\text { Vinasse } \\
50 \%\end{array}$ & $\begin{array}{c}\text { Vinasse } \\
100 \%\end{array}$ & Mean \\
\hline & $\mathbf{0}$ & 0.503 & 0.543 & 0.547 & 0.531 & 1.26 & 1.767 & 2.083 & 1.703 & 0.917 & 1.040 & 1.113 & 1.023 \\
\hline & 1 & 0.503 & 0.547 & 0.593 & 0.548 & 1.267 & 2.063 & 2.287 & 1.872 & 0.940 & 1.183 & 1.280 & 1.134 \\
\hline \multirow[t]{3}{*}{ GA (\%) } & 2 & 0.527 & 0.610 & 0.757 & 0.631 & 1.327 & 2.833 & 3.743 & 2.634 & 0.967 & 1.387 & 2.007 & 1.453 \\
\hline & 4 & 0.533 & 0.683 & 0.940 & 0.719 & 1.370 & 3.487 & 4.773 & 3.210 & 0.973 & 1.733 & 2.163 & 1.623 \\
\hline & 1 & 0.513 & 0.563 & 0.593 & 0.557 & 1.310 & 2.150 & 2.633 & 2.031 & 0.957 & 1.217 & 1.377 & 1.183 \\
\hline \multirow[t]{2}{*}{$\operatorname{Li}(\%)$} & 2 & 0.533 & 0.633 & 0.823 & 0.663 & 1.423 & 3.330 & 4.377 & 3.043 & 0.987 & 1.513 & 2.010 & 1.503 \\
\hline & 4 & 0.537 & 0.753 & 0.870 & 0.720 & 1.527 & 3.707 & 4.270 & 3.168 & 1.013 & 1.987 & 2.080 & 1.693 \\
\hline \multicolumn{2}{|l|}{ Mean } & 0.521 & 0.619 & 0.732 & & 1.355 & 2.762 & 3.452 & & 0.965 & 1.437 & 1.719 & \\
\hline \multirow{3}{*}{$\operatorname{LSD}(0.05)$} & $\mathbf{F}$ & \multicolumn{4}{|c|}{0.022} & \multicolumn{4}{|c|}{0.100} & \multicolumn{4}{|c|}{0.038} \\
\hline & $\mathbf{E}$ & \multicolumn{4}{|c|}{0.013} & \multicolumn{4}{|c|}{0.125} & \multicolumn{4}{|c|}{0.032} \\
\hline & $\mathbf{F} * \mathbf{E}$ & \multicolumn{4}{|c|}{0.022} & \multicolumn{4}{|c|}{0.216} & \multicolumn{4}{|c|}{0.056} \\
\hline \multicolumn{14}{|c|}{ Second Season $(2018 / 2019)$} \\
\hline \multirow{3}{*}{ GA (\%) } & $\mathbf{0}$ & 0.490 & 0.557 & 0.593 & 0.547 & 1.327 & 2.137 & 2.227 & 1.897 & 0.923 & 1.117 & 1.200 & 1.080 \\
\hline & 4 & 0.537 & 0.787 & 0.973 & 0.766 & 1.757 & 2.887 & 3.927 & 2.857 & 0.990 & 1.957 & 2.220 & 1.722 \\
\hline & 1 & 0.513 & 0.660 & 0.713 & 0.629 & 1.403 & 2.247 & 2.453 & 2.034 & 0.947 & 1.403 & 1.587 & 1.312 \\
\hline \multirow[t]{2}{*}{$\operatorname{Li}(\%)$} & 2 & 0.543 & 0.747 & 0.863 & 0.718 & 1.843 & 2.503 & 3.897 & 2.748 & 1.010 & 1.830 & 2.157 & 1.666 \\
\hline & 4 & 0.547 & 0.810 & 0.903 & 0.753 & 1.860 & 2.933 & 3.607 & 2.800 & 1.083 & 2.010 & 2.177 & 1.757 \\
\hline \multicolumn{2}{|l|}{ Mean } & 0.526 & 0.702 & 0.794 & & 1.567 & 2.494 & 3.169 & & 0.981 & 1.627 & 1.842 & \\
\hline \multirow{3}{*}{$\operatorname{LSD}(0.05)$} & $\mathbf{F}$ & \multicolumn{4}{|c|}{0.013} & \multicolumn{4}{|c|}{0.044} & \multicolumn{4}{|c|}{0.011} \\
\hline & $\mathbf{E}$ & \multicolumn{4}{|c|}{0.015} & \multicolumn{4}{|c|}{0.042} & & & & \\
\hline & $F^{*} \mathbf{E}$ & & & & & & & & & & & & \\
\hline
\end{tabular}




\section{References}

Abd El-Azim, W.M., R.M.R. Khater and M.Y.M Badawy, 2017. Effect of bio-fertilization and different licorice extracts on growth and productivity of Foeniculum vulgare, Mill. plant. Middle East J. of Agri. Res., 6: 01-12.

Al-Obady, R.M ., 2015. Effect of foliar application with garlic extract and Liquorice root extract and Salicylic acid on vegetative growth and flowering and flower set of tomato and under unheated houses. J. of Appl. Sci. And Research, 3(1):11-22.

A.O.A.C. Association of Official Analysis Chemists, 1990. Official Methods of Analysis $15^{\text {th }}$ Ed. Washington, D.C., USA.

Arafat, S. and A. E. Yassen, 2002. Agronomic evaluation of fertilizing efficiency of vinasse. 17th World Cong., Soil Sci. Symp, 14: 1-6.

Bradley, P., 2006. British Herbal Compendium, Volume 2. British Herbal Medicine Association, Bournemouth.

British Pharmacopoeia, 2000 . Determination of Volatile Oil in Drugs. The Pharmaceutical press. London. pp. 1914.

Champman, H.D. and Pratt, 1961. Methods of Analysis of Soil, Plant and Water. Univ. Calf.

Cheng, Z.H., C.H. Wang, X.M. Xiao and M.A. Khan, 2011. Allelopathic effects of decomposing garlic stalk on some vegetable crops. Afr. J. Biotechnolology, 10(69):15514-15520.

Cheng, F., Z.H. Cheng and H.W. Meng, 2016. Transcriptomic insights into the allelopathic effects of the garlic allelochemical diallyl disulfide on tomato roots. Sci. Rep. 6, 38902.

Ding, H., Z. Cheng, L. Menglong, S. Hayat and H. Feng, 2016. Garlic exerts allelopathic effects on pepper physiology in a hydroponic co-culture system. Biology Open, 5(5):631-637.

Duke, J. A. , 1992) Handbook of Phytochemical Constituents of GRAS Herbs and Others Economic Plants. Boca Raton FL. CRC Press.

El-Desouky, S.A., A.L.A. Wanas and Z. M. A. Khedr, 1998. Utilization of some natural plant extracts (of garlic \& yeast) as seed-soaked materials to squash (Cucurbita pepo L.. 1- Effect on growth, sex expression and fruit yield \& quality. Annals of Agric. Sci. Moshtohor, 36(2): 839-854.

El-Said, N.A.M. and H.M.H. Ali , 2013. Physiological effects of garlic aqueous extract on cumin. Egypt. J. Hort., 40(2): $247-260$.

El-Shayeb, N.S.A., 2009. Physiological studies on Oenothera biennis. Ph. D. Thesis of Ornamental Horticulture Department Faculty of Agriculture at Moshtohor Zagazig University (Banha Branch.

Fathel, H.B, A.F. Qasim and T.A. Zhuan, 2015. Effects of gibberellic, salicylic acid and liquorice extract in yield, quality flowers carnation and the essential oil content. J. Agric. Sci., Tikrit Uni.,15(1):31-46.

Gomez, K. and A. Gomez, 1984. Statistical Procedures. Agric. Res., $2^{\text {nd }}$ Ed. John Wiley and Sons, Inc, New York, USA.

Gupta, A., M. Dubey, M. Parmar, S. Mahajan and R. Sharma , 2011. Evaluation of Antimicrobial activity of Carum carvi (seeds) extract against E. coli and Aspergillus niger. Drug Invention Today, 3, 211-213.

Hanafy, M.S., F.M. Saadawy, S.M.N. Milad and R.M. Ali , 2012. Effect of some natural extracts on growth and chemical constituents of Schefflera arboricola plants. J. of Hortic. Sci. \& Ornam. Plants, 4 (1): 26 - 33.

Husain, W. . and F.H. El-Rekaby, 2006. Response of cucumber plants to foliar spray with garlic, licorice extract and urea on growth and yield. Iraqi J. Agric. Sci., 37(4): 33-38.

Jiang, Z.P., Y.R. Li, G.P. Wei, Q. Liao, T. M. Su, Y.C., H.Y. Meng Zhang and C.Y. Lu, 2012. Effect of long-term vinasse application on physico-chemical properties of sugarcane field Soils. Sugar Technol., 14(4): 412-417.

Kamal, A.M. and K.M. Ghanem , 2012. Impact of some bio-stimulants on organically cultivated snap bean plants, Egypt. J. of Appl. Sci., 27(2): 89-104.

Kamenik, J., 1996. Perspektivy uplatneni Kminu V zemédélstive CR. In: Proc. Conf. Biologie and agrotechnique of caraway. MZLU Brno: $8-10$.

Kluszczyñska, D., 2002. Caraway in medical care and housekeeping. Wiad. Ziel., 44(4): 13-15. 
Laribi B., I. Bettaieb, K. Kouki, A. Sahli, A. Mougou and B. Marzouk, 2009. Water deficit effects on caraway (Carum carvi L.) growth, essential oil and fatty acid composition. Ind. Crop. Prod., 30: 372-379.

Mohamed, H.I and S.A. Akladious, 2014. Influence of garlic extract on enzymatic and non-enzymatic antioxidants in soybean plants (Glycine Max) grown under drought stress. J. Life Sci., 11(3): 46-58.

Morsi, M.K., B. El-Magoli, N.T. Saleh, E.M. El-Hadidy and H.A. Barakat, 2008. Study of antioxidants and anticancer activity licorice Glycyrrhiza glabra extracts. Egyptian J. Nutr. and Feeds, 2(33): 177-203.

Murphy, J.P. and J.A Riley, 1962. Modified single solution method for the determination of phosphate in natural waters. Anal. Chim. Acta., 27: 31-36.

Nasser, N.S, M.W Mahdi and S.S. Abdullah , 2014. The effect of spraying with licorice extract and organic fertilization of poultry in the growth of fenugreek plant (Trigonella foenum- graecum L.. The Swedish Journal of Scientific Research (SJSR), 1: 36-42.

Nour Eldeen, E.A. , 2014. Effect of bio- fertilizers and plant extracts on growth and chemical constituents under water stress conditions of sage (Salvia officinalis L.) plant. Ph. D. Thesis, Fac. Agric., Mansoura Univ.

Olle, M. and I. Bender, 2010. The content of oils in umbelliferous crops and its formation. Agron. Res., 8: 687- 696.

Omar, M.N.A.; A.T. Mostafa and A. S. Ahmed , 2000. Concentrated vinasse as a Novel Diazotrophs growth Medium (biovinasse inoculant) and soil conditioner to improve faba bean yield under dripping irrigation system. Proceedings of The Tenth Microbiology Conference, Cairo, Egypt, 100-109.

Osman, Mona A., 2010. The Possible use of diluted vinasse as a partial replacement with mineral fertilizers source on wheat yield and nutritional status on sandy soil. Nature and Science, 8(11): 245-251.

Page, A.L., R.H. Miller and D.R. Keeney, 1982. Methods of soil analysis. Part II-Chemical and microbiological properties. A.S.A. Madison Wisc., USA.

Parnaudeau, V., N. Condom, R. Oliver, P. Cazevieille and S. Recous, 2007. Vinasse organic matter quality and mineralization potential, as influenced by raw material, fermentation and concentration processes. (C.F Science directBioresource Technology.

Rice, F. L, 1984. Allelopathy. $2^{\text {nd }}$ ed., F. D. Academic Press, Inc., Orlando, FI 422 p.

Sachan A.K., N.K. Sachan, S. Kumar, A. Sachan and S.S. Gangwar, 2010. Evaluation and standardization of essential oils for development of alternative dosage forms. Eur. J. Sci. Res., 46: 194- 203.

Samojlik, I., N. Lakic, N. Mimica-Dukic, K. Djakovic-Svajcer and B. Bozin , 2010. Antioxidant and hepatoprotective potential of essential oils of coriander (Coriandrum sativum L.) and caraway (Carum carvi L.)(Apiaceae. J. of Agric. Food Chem., 58: 8848-8853.

Şanli, A., T. Karadoan, M. Tonguç and H. Baydar, 2010. Effects of caraway (Carum carvi L.) seed on sprouting of potato (Solanum tuberosum L.) tubers under different temperature conditions. Turkish J. of Field Crops, 15: 54-58.

Seddik, Wafaa M.A., 2011. Evaluation of vinasse, organic manure and natural minerals as alternative natural fertilizers. J. Bio. Chem. Environ. Sci., 6: 269- 292.

Shabani L., A.A. Ehsanpour, G. Asghari and J Emami, 2009. Glycyrrhizin production by in vitro cultured Glycyrrhiza glabra elicited by Methyl Jasmonate and salicylic acid. RUSS J PLANT Physl, 56: 621-626.

Shang-Dong, Y., L. Jun-Xian, W. Jun, T. Hong-Wei and L. Yang-Rui , 2013. Effect of vinasse and press mud application on the biological properties of soils and productivity of sugarcane. J. of Sugar Tech., 15:152-158.

Silva, J., J. Cazetta and A. Togoro , 2015. Soil change induced by the application of biodigested vinasse concentrate and its effects on growth of sugarcane. Chilean J. Agric. Res. [online], 75(2): 249-254.

Ullah, I.M., U.R. Rahman and Y. Zafar, 2006. Genotypic variation for drought tolerance in cotton (Gossypium hirsutum L.): seed cotton yield responses. Pak. J. Bot., 38(5):1679-1687. 
Vadivel, R., S. M. Paramjit, K.P. Suresh, S. Yogeswar, R.D.V.K. Nageshwar and N. Avinash, 2014. Significance of vinasses waste management in agriculture and environmental quality- Review. African J. Agric. Res., 9: 2862-2873.

Wang, C.H., Z.H. Cheng and Q. Niu , 2009. Allelopathy of ultrasonic extract of garlic plant on different receiver vegetable crops. Agricultural Science and Technology Information (AGRIS), 37: 103-109.

Wei, L., Z. H Cheng and L. Zhang, 2008. Allelopathy of straw aqueous extracts of different garlic varieties on tomato (Lycopersicon esculentum. J. Northwest A \&F Univ. Natur. Sci. Edit, 36(10):139-145.

Zeng, R.S., 2008. Allelopathy in Chinese ancient and modern agriculture, in Allelopathy in Sustainable Agriculture and Forestry, eds Zeng R., Mallik A., Luo S., editors. (New York: Springer New York Press), 39-59.

Zeng, R. S., 2014. Allelopathy the solution is indirect. J. Chem. Ecol., 40: 515-516.

Zhou, Y.L., Y. Wang, J.Y. Li and Y.J. Xue, 2011. Allelopathy of garlic root exudates. Chin. J. Appl. Ecol., 22(5): 1368-1372.

Ziedan, E.H. and E.A. Eisa, 2016. The use of some micronutrients and plant extracts of resistance to powdery mildew and nutrition dill plants in the Gharbiyah governorate. J. Plant Prot. and Path., Mansoura Univ., 7 (9): 579 - 586.

Zuhair, A.D. , 2010. Effect of foliar spray of zinc and liquorice root extract on some vegetative and flowering growth parameters of two strawberry varieties (Fragaria $x$ ananassa Duch.), Mesopotamia J. of Agric., 38: 152-161. 